\title{
IMMUNOPATHOLOGIC STUDIES IN MYOCARDIAL BIOPSIES OF PATIENTS WITH CHAGAS' DISEASE AND IDIOPATHIC CARDIOMYOPATHY
}

\author{
Marfa de Lourdes HIGUCHI; Edgard Augusto LOPES; Luis Balthazar SALDANHA; Antonio Carlos \\ Pereira BARReTTO; Noedir A. G. STOLF; Giovanni BELLOTTI \& Fulvio PILEGGI
}

\section{S U M M A R Y}

Right ventricular endomyocardial biopsies were studied in 30 patients, 15 with myocardiopathy from chronic Chagas'disease and 15 with idiopathic congestive myocardiopathy; five other myocardial samples were taken at necropsies of patients with chronic Chagas' disease. The authors tried to establish by means of direct immunofluorescence techniques whether there were immunoglobulins $G, A$ and $M$, fibrinogen and $C_{3}$ complement deposition in the myocardium; only one of these 30 patients exhibited a positive reaction to IgG, it was a patient with idiopathic congestive myocardiopathy. All fragments from patients with Chagas' disease showed no response to any of the fluorescent conjugates. These findings do not support the idea that anti-myocardial antibodies have pathogenic importance in the evolution of dilated or chagasic myocardiopathies.

KEY WORDS: Chagas' disease - myocardial biopsy - idiopathic cardiomyopathy - immunopathology.

\section{N T R O D U C T I O N}

Dilated cardiomyopathy may be the final common pathway of a variety of myocardial insults. Serum factors reactive to heart muscle constituents and an autoimmune response have been suggested as possible factors in the pathogenesis of these cardiomyopathies $1,2,6,12,16$. However, these results were not confirmed by other investigations $7,10,11,18$. Such divergences may be related to different ways of reading immunofluorescent slides or to artefacts.

In chronic Chagas' disease, COSSIO et a1.,35 and more recently MOLINA et al. ${ }^{14}$, reported antibodies to endothelial cells and plasmatic membranes of striated and cardiac muscles (EVI factor).

As the significance and reproducibility of these findings remain unclear, this paper re- ports results obtained by direct immunofluorescence studies of myocardial biopsy specimens from patients with chronic Chagas' heart disease and from patients with idiopathic dilated cardiomyopathy.

\section{MATERIAL AND METHODS}

The material consisted of 30 myocardial samples obtained by endomyocardial biopsy and five heart samples taken from autopsied patients up to two hours after death.

Fifteen out of the 30 patients had serolo gically confirmed Chagas' chronic disease; six of these had normal electrocardiogram (ECG) and normal heart radiologic study; two had no heart failure and no cardiomegaly at X-ray but

From the Heart Institute of Clinical Hospital - Säo Paulo University School of Medicine. Adciress for reprints: Maria de Lourdes Higuchi. Instituto do Coraçāo - Hospital das Clínicas FMUSP - São Paulo - Brasil - CEP 05403. This study was supported in part by FINEP 
HIGUCHI, M. de L.; LOPES, E. A.; SALMANHA, L. B.; BARRETTO, A. C. P.; STOLF, N. A. G.; BELLOTTI, G. \& PLLEGGI, F. - Immunopathologic studies in myocardial biopsies of patients with Chagas'disease and idiopathic cardiomyopathy. Rev. Inst. Med. trop. São Paulo, 28:87-90, 1986.

presented abnormal ECG; seven had congestive heart failure, abnormal ECG and cardiomegaly at X-ray. The fifteen remaining patients had idiopathic congestive cardiomyopathy (dilated cardiomyopathy).

All biopsies were performed on the right aspect of the ventricular septum using the $\mathrm{Ca}$ ves Schultz transvenous biopsy forceps through the right internal jugular vein. The techniques used were similar to those described by MASON 13 .

In five additional cases, specimens were collected at necropsy from patients with chronic Chagas' heart disease, all of them with a history of congestive heart failure.

As controls, samples from two hearts ob. tained at autopsy were used: one from a patient with systemic arterial hypertension and the other from a patient with congenital heart disease. Six specimens from normal skeletal muscle were also used as controls. A sample of skeletal muscle with myositis. in which immunoglobulins were previously detected, was used.as a positive control.

Biopsy specimens were immediately frozen in liquid Nitrogen and sectioned with an American Otpical criostate. Sections were washed with PBS during ten minutes and then placed in a alcohol-ether solution during five minutes. Afterwards, the slides were washed three times, during ten minutes each, with PBS. They were then incubated during 30 minutes with 5 isothiocyanate-conjugated rabbit anti-human globulins (anti-IgG, anti-IgA, anti-IgM, anti-fibrinogen and anti- $\mathrm{C}_{3}$ complement - Behring Institute) at titers of $1: 20,1: 40,1: 30,1: 20$ and $1: 40$ res. pectively. After incubation the specimens were washed with PBS and the slides analysed with a Zeiss fluorescent microscope.

\section{RESULTS}

Heart samples from biopsies did not show fluorescence with any of the three different anti-globulins nor with fibrinogen or $\mathrm{C}_{3}$ in 29 out of 30 specimens. The only positive sample came from a patient with idiopathic congestive myocardiopathy. The immunofluorescence was of moderate intensity; it was only observed with conjugated anti-IgG in a granulous pattern at the sarcolema and without complement deposition. None of the autopsy samples were positive. Cardiac and skeletal muscle controls were all negative while the positive control reacted adequaly with all 5 conjugates.

\section{DISCUSSION}

In 1974 COSSIO et al ${ }^{3,4}$ first reported that in Chagas' disease, indirect immunofluorescent techniques revealed anti-heart globulins against endocardium, interstitium and blood vessels the so called endocardial - vascular - interstitium factor (EVI). The Authors claimed a greater frequency of positive results in the symptomatic patient group as compared with asymptomatic patients. suggesting the possibi: lity that positive reactors could be future symptomatic patients ${ }^{3}$. They suggested that the EVI factor showed a good specificity for Chagas' disease.

In 1977, the same Authors, using biopsy material, reported positive results with anti-IgG globulin reacting against sarcolemma in all of four Chagas' disease patients under study (two asymptomatic and two with overt heart disease). Three of these biopsies exhibited com. plement deposition.

More recent reports, however, though demonstrating a high positive incidence of EVI factor in serum of patients with Chagas' disease, did not show a significant difference between the various clinical groups 15,17 .

Recently MOLINA et al. 14 reported the presence of $\operatorname{IgA}, \operatorname{IgG}, \operatorname{IgM}$ and $\mathrm{C}_{3}$ in the interstitium, capillaries and endocardium of 4 out of 4 chagasic patients.

Our results, however, do not show similar patterns of reaction. Out of 15 endomyocardial biopsy specimens from confirmed Chagas' heart disease in different clinical forms, none showed positivity with any of the antibodies, nor with complement or fibrinogen. We believe that the diverging results are due to different ways of interpreting slide readings. Interstitium collagen and elastic fibers from different organs, frequently become impregnated by antisera and under ultraviolet light acquire a tarnished green which is different from the light green usually seen in true positive immunofluorescence. Other 
FIGUCHI, M. de L.; LOPES, E. A.; SALDANHA, L. P.; BARRETTO, A. C. P.; STOLF, N. A. G.; BELLOTTI, G. \& PILEGGI, F. - Immunopathologic studies in myocardial biopsies of patients with Chagas'disease and idiopathic cardiomyopathy, Rev. Inst. Med. trop. Sāo Paulo, 28:87-90, 1986.

artefactual aspects seen at the periphery of fragments may be due to the easier impreg. nation, which make remotion, by multiple washings more difficult. These areas frequently give false positive immunofluorescence. These two aspects should be considered when trying to explain the divergent results described in the above mentioned papers.

Thus the complete lack of anti-myocardial antibodies in chronic Chagas' heart disease precludes any pathogenic influence of the EVI factor. In this connection, it may be noted that KHOURY et al. have recently cast doubt on earlier results by COSSIO et al, 3,5 suggesting that the presence of a heterophil antibody might explain the earlier finding.

Anti-myocardial globulins have also been described in patients with idiopathic dilated cardiomyopathy, in higher titers than those of control populations. This finding may suggest participation of the immune mechanism in the genesis of cardiac lesions $2,6,9,12,16$.

BOLTE et al.2 found IgG deposit at the sarcolemmal region in $81 \%$ of their cases using direct immunofluorescence technique in endomyocardial biopsies. These authors suggested a correlation between the frequency of positivy and the intensity of myocardial alterations.

However, other Authors also investigating anti-myocardial antibodies with direct or indirect immunofluorescent techniques in biopsy specimens, did not confirm these results $10,11,18$. THOMPSON et al..$^{18}$ found only artefactual inespecific fluorescence similar to that seen in control groups. KOMADJA et al."1 in a study with 37 serological samples and eight endomyocardial biopsies from patients with dilated idiopathic myocardiopathies using the indirect immunofluorescent method found only one positive result.

Our study showed one positive result, and only with IgG, in a case of dilated myocardiopathy without complement deposition or reaction with other classes of immunoglobulin. Some of the other biopsy. specimens showed an interstitial fluorescence with the conjugated anti-IgG that was apparently inespecific and some fragments exhibited a greenish non fluorescent color.
Our findings were similar to those of THOMPSON et al. ${ }^{18}$ and KOMADJA et $a .^{10}$ and we entirely agree with them as regards the fact that anti-myocardial antibodies have no pathogenetic influence upon congestive myocardial disease.

\section{RESUMO}

Estudos imunopatológicos de biópsias de pacientes chagásicos crônicos ou com miocardiopatia dilatada idiopática.

Foram estudadas biópsias de ventrículo đireito de 30 pacientes, 15 com doença crônica de Chagas e 15 com miocardiopatia congestiva idiopática. Analisou-se também cinco fragmentos miocárdicos obtidos de pacientes chagásicos com menos de duas horas de óbito. Os Autores tentaram estabelecer, por meio de técnica de imunofluorescência direta, a presença de imunoglobulina $G$, A, e $M$, fibrinogênio e $C_{3}$. Somente uma das 30 biópsias exibiu reação positiva para IgG que era de um paciente com miocardiopatia congestiva idiopática. Toods os fragmentos provenientes de pacientes chagásicos não apresentaram qualquer fluorescência com nenhum dos conjugados.

Esses achados falam contra o conceito de que anticorpos antimiocárdio teriam importância patogenética na evolução das miocarđiopatias chagásica ou dilatada idiopática.

\section{ACKNOWLEDGEMENT}

The Authors gratefully acknowledge Prof. Mauricio Rocha e Silva, M.D., for his generous cooperation and the revision of this article.

\section{REFERENCES}

1. BOLTE, H. D.; FISCHER, S. \& LUDWIG, B. - Immunological examinations in dilated cardiomyopathies Z. KardloI., 71: 517.521, 1982.

2. BOLTE, H. D. \& SCHULTHEISS, P. - Immunological results in myocardial diseases. Postgrad. med. J. 54: $500-503,1978$.

3. COSSIO, P. M.; DIEZ, C.; SARFMAN, A.; KREUTZER. E.: CANDIOLO, B. \& ARANA, R. M. - Chagasic cardiopathy: demonstration of serum gammaglobulin fac tor which reacts with endocardium and vascular struc tures, Circulation, 49: 13-21, 1974. 
HIGUCHI, M. de tr; LOPES, E. A.; SALDANHA, L. B.; BARRETTO, A. C. R.; STOLF, N. A. G.; BELLOTTI, G. \& PILEGGI, F. - Immunopathologic studies in myocardial biopsies of patients with Chagas'disease and idiopathic cardiomyopathy. Kev. Inst. Med. trop. São Paulo, 28:87-90, 1986.

4. COSSIO, P. M.; LAGUENS, R. P.; DIEZ, C.; SZARFMAN, A.; SEGAL, A. \& ARANA, R. M. - Chagasic cardiopathy: antibodies reacting with plasma membrane of striated muscle and endothelial cells. Circulation, 50: 1252-1259, 1974.

5. COSSIO, P. M.; LAGUENS, R. P.; KREUTZER, E.; DIEZ, C.; SEGAL, A. \& ARANA, R. M. - Chagasic cardiopathy: immunopathologic and morphologic studies in myocardial biopsies, Amer. J. Path., 86: 533. $539,1977$.

6. DAS, S. K.; CALLE, J. P.; DODSON, V. N. \& CASIDY, J. T. - Immunoglobulin binding in cardiomyopathy hearts. Girculation, 44: 612-616, 1971.

7. FLETCHER, F. G. \& WENGER, N. K. - Autoimmune studies in patients with primary myocardial disease. Circulation, 37: 1032-1035, 1968.

8. KHOURY, E. L.; DIEZ, C.; COSSIO, P. M. \& ARANA, R. N. - Heterophil nature of EVI antibody in Try. panosoma cruzi infection. Clin. Immunol. Immunopath., 27: $283-288,1983$.

9. KLAJMAN, A.; KAMIN-BELSKY, N.; FELDMAN, S. \& KARIV, I. - Immunologic studies in familial cardiomyopathy. Amer. J. Cardiol. 28: 707-711, 1971.

10. KOMAJDA, M.; BEAUFILS, H.; MOULIAS, R.; MA RESCOT, M. R.; BROBINSKY, G. \& GROSGDGEAT, $\mathrm{X}$. - Etude immunologique dans les myocardiopathies primitives non obstructives. A propos de 37 observations. Ann. Méd. intern., 130: 547-551, 1979.

11. KOMAJDA, M.; BEAUFILS, H.; SCHMELCK, P. H.; MUNICH, A.; DROBINSKI, G.; THOMAS, D.; MOULIAS, R. \& GROSGOGEAT, Y. - Etude immunologique dans les myocardiopathies dilatées. Arch. Mal. Coeur., 75: 29-35, 1982
12. MAISCH, B.; BERG, P. A. \& KOCHSIEK, K. - Im munological parameters in patients with congestive cardiomyopathy. Basic Res. Cardiol, 75: 221-222, 1980.

13. MASON, J. N. - Techniques for right and left ventricular endomyocardíal biopsy. Amer, J. Cardiol., 41: 887.892, 1978.

14. MOLINA, H. A.; MILEI, J. \& STORINO, R. - Chro. nic Chagas' myocardiopathy. Demonstration of "in vivo" bound immunoglobulins in heart structures by the immunoperoxidase technique. Cardiology, 71: 297-206, 1984.

15. PERalita, J. M.; Manigot, D. A.; MUSCellit, E. O A.; MAGALHĀES, T. C. R.; ALMEIDA, E. A. \& BASTOS, A. - Anticorpo EVI e.NP na infecção chagásica crónica. Estudo em pacientes com diferentes formas clinicas. Rev. Inst, Med. trop. S. Paule, 24: 6-10, 1982.

16. SANDERS, V. \& RITS, R. E. - - Ventricular localization of bound gamma globulin in idiopathic disease of the myocardium. J. Amer. med. Ass. 194: 171.173, 1965

17. SZARFMAN, A.; LUQUETTI, A.; RASSI, A.; REZEN DE, J. M. \& SCHMUNIS, G. A. - Tissue-reacting immunoglobulins in patlents with different clinical forms of Chagas' disease, Amer. J. trop. Med. Hyg., 30: 43.46, 1981 .

18. THOMPSON, R. A.; TRUEMAN, T.; HAENEY, M. R.: HATCHETT, M.; LITTLER, W. A. \& RETIER, L. Immunological mechanisms and cardiomegaly. Lancet, 5: $7.48,1980$

Recebido para publicaçāo em 16/5/1985. 